BUDGETING : Journal of Business, Management and Accounting

Volume 2, Nomor 2, Januari-Juni 2021

e-ISSN: 2715-2480

p-ISSN: $2715-1913$

DOI: https://doi.org/10.31539/budgeting.v2i2.1749

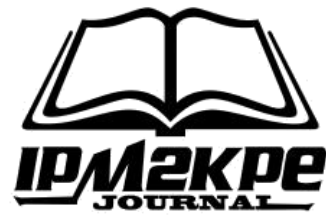

\title{
EVALUASI PENERAPAN CORPORATE SOCIAL RESPONSIBILITY PADA PROGRAM KEMITRAAN DAN BINA LINGKUNGAN
}

\author{
Rian Febri Anwari \\ Universitas Muhammadiyah Jember \\ rianonfire027@gmail.com
}

\begin{abstract}
ABSTRAK
Penelitian ini bertujuan untuk mengetahui penerapan Corporate Social Responsibility (CSR) PT. Industri Gula Glenmore (IGG) yang berbentuk program kemitraan dan bina lingkungan dalam pemberdayaan masyarakat sekitar perusahaan. Penelitian ini merupakan penelitian deskriptif dengan pendekatan kualitatif. Penentuan subjek penelitian ini menggunakan teknik purposive sampling. Teknik pengumpulan data yang digunakan adalah observasi, wawancara dan dokumentasi. Hasil penelitian menunjukkan bahwa program-program yang dilaksanakan oleh PT. IGG diantaranya adalah kemitraan, bantuan sarana prasarana dan bantuan pendidikan. Strategi yang digunakan dalam pelaksanaan CSR PT. IGG adalah Mixed Type. Prinsip yang digunakan dalam pelaksanaan CSR PT. IGG adalah keberlanjutan, pertanggungjawaban dan keterbukaan. Program kemitraan termasuk dalam kategori community development dan bina lingkungan termasuk dalam kategori community philantrophy. Simpulan, pimpinan turut andil dalam pelaksanaan CSR di PT. IGG. Transparansi berupa pelaporan kegiatan CSR dilakukan setiap tiga bulan sekali dengan cakupan wilayah yaitu pada masyarakat sekitar PT. IGG. Adapun pada kegiatan monitoring yang dilaksanakan masih belum maksimal, dimana terdapat masalah berupa pengembalian pinjaman dari mitra binaan yang terhenti. Pelibatan stakeholder yaitu pada program kemitraan. Hasil nyata ditunjukkan oleh mitra binaan yang sudah berhasil mandiri. Program Kemitraan dan Bina Lingkungan berlanjut setiap tahun.
\end{abstract}

Kata Kunci: Bina Lingkungan, Corporate Social Responsibility, Program Kemitraan

\section{ABSTRACT}

This study aims to determine the implementation of Corporate Social Responsibility (CSR) PT. Glenmore Sugar Industry (IGG), which is in the form of a partnership program and community development, empowers the community around the company. This research is a descriptive study with a qualitative approach. Determination of the subject of this study using a purposive sampling technique. The data collection techniques used were observation, interview and documentation. The results showed that the programs implemented by PT. IGG includes partnerships, infrastructure assistance and educational assistance. The strategy used in implementing the CSR of PT. IGG is a Mixed Type. The principles used in implementing the CSR of PT. IGG is sustainability, accountability and openness. The partnership program is included in community development and community development is included in the category of community philanthropy. In conclusion, the leadership takes part in implementing CSR at PT. IGG. Transparency in the form of reporting on CSR activities is carried out every three months with the community's coverage area around PT. IGG. The monitoring 
activities carried out are still not optimal, where there are problems in the form of loan repayments from fostered partners that have stopped. Stakeholder involvement, namely in the partnership program. Real results are shown by the enabled partners who have succeeded independently. The Partnership and Community Development Program continues every year.

Keywords: Community Development, Corporate Social Responsibility, Partnership Program

\section{PENDAHULUAN}

Keberadaan suatu perusahaaan dalam lingkungan masyarakat akan hidup, tumbuh dan berkembang dengan baik apabila mendapatkan dukungan dari masyarakat. Masyarakat merupakan pemasok utama kebutuhan perusahaan akan sumber daya manusia dan pemakai produk dari perusahaan. Perusahaan tidak hanya beroperasi untuk meraih keuntungan saja, tetapi juga memperhatikan kepentingan masyarakat, yang dibutuhkan masyarakat dan melestarikan lingkungan. Menurut Lako (2011) agar bisnis korporasi bisa tumbuh secara berkelanjutan hanya ada satu pilihan, yaitu menyelaraskan pencapaian kinerja laba (profit) dengan kinerja sosial (people) dan kinerja lingkungan (planet) secara berkesinambungan. Pendapat tersebut dimaksudkan agar perusahaan tidak hanya berfokus pada keuntungan, namun juga bertanggung jawab akan dampak dari aktivitas serta kondisi lingkungan sosial perusahaan.

Perusahaan menjalin hubungan baik dengan masyarakat melalui program yang dikenal dengan istilah Corporate Social Responsibility (CSR). Pemerintah melalui Undang-Undang Perseroan Terbatas (UUPT) Nomor 40 Tahun 2007 mewajibkan bagi perusahaan untuk melaksanakan program atau tanggung jawab sosial perusahaan (CSR). CSR merupakan bentuk kepedulian perusahaan terhadap pihak pihak yang terkait oleh perusahaan. Kajian ruang lingkup CSR dalam arti sempit dimulai dari perkembangan terhadap karyawan, dilanjutkan dengan stakeholder dan masyarakat umum. Stakeholder adalah semua pihak baik internal maupun eksternal yang memiliki hubungan baik bersifat mempengaruhi maupun dipengaruhi, bersifat langsung maupun tidak langsung oleh perusahaan.

Menurut Ariana (2018) terdapat dua stakeholder yang ada dalam ruang lingkup CSR yaitu: 1) masyarakat lokal, yaitu masyarakat yang berada di sekitar korporasi beroperasi; 2) masyarakat yang tidak mempunyai hubungan secara kontraktual dengan korporasi, masyarakat umum, bukan konsumen atau pihak ketiga lainnya. Kegiatan 
CSR yang dilakukan perusahaan secara terus menerus merupakan salah satu cara untuk mencegah konflik melalui peningkatan citra perusahaan. Tujuan melakukan CSR adalah untuk membangun hubungan baik dengan masyarakat, sehingga terbentuk sikap publik yang baik dan membangkitkan kepercayaan publik kepada perusahaan.

Selain sebagai institusi bisnis, perusahaan juga tidak dapat dilepaskan dari keberadaan sebagai entitas sosial (corporate citizenship) yang berpengaruh dan dipengaruhi oleh kondisi lingkungan sekitarnya. Oleh karena itu, keberadaan korporasi sudah selayaknya memberikan kemanfaatan umum terutama bagi masyarakat sekitar. Pentingnya CSR sebagai bagian dalam aktivitas perusahaan juga disadari oleh PT. Industri Gula Glenmore (IGG). Tujuan yang ingin dicapai dari pelaksanaan program ini adalah untuk menciptakan keharmonisan antara perusahaan dengan masyarakat sekitar.

Aktivitas produksi PT. IGG menghasilkan limbah padat dan limbah cair. Salah satu jenis limbah padat adalah sisa perasan tebu dan limbah blotong. Limbah cair berasal dari proses pencucian dan pemasakan yang menghasilkan efek asam atau alkali. Limbah cair merupakan salah satu polutan yang berbahaya dan mencemari lingkungan karena bau dan warnanya yang hitam kecoklatan (Amin, 2012). Hal ini tentu saja dapat merusak atau mengganggu hubungan antara perusahaan dengan masyarakat sekitar. Oleh karena itu, peneliti tertarik untuk mengkaji mengenai penerapan Corporate Social Responsibility (CSR) PT. Industri Gula Glenmore yang berbentuk program kemitraan dan bina lingkungan dalam pemberdayaan masyarakat sekitar perusahaan.

\section{KAJIAN PUSTAKA}

\section{Definisi Corporate Social Responsibility (CSR)}

Menurut bahasa corporate sosial responsibility diartikan sebagai tanggung jawab sosial perusahaan. Undang-Undang Nomor 40 Tahun 2007 tentang Perseroan Terbatas memilih menggunakan istilah tanggung jawab sosial dan lingkungan untuk penjabaran dalam pengaturan tersebut. Saat ini belum ada kesatuan bahasa terhadap istilah CSR namun secara konseptual semuanya memiliki kesamaan makna.

Secara teoritis, CSR dapat didefinisikan sebagai tanggung jawab moral suatu peusahaan terhadap para stakeholdernya, terutama komunitas atau masyarakat di sekitar wilayah kerja atau operasionalnya. Azheri (2012) mengatakan bahwa perusahaan bukan lagi sebagai entitas yang hanya mementingkan diri sendiri (selfish) dan/atau 
eksklusivitas dari lingkungan masyarakat, tetapi sebagai sebuah entitas badan hukum yang wajib melakukan adaptasi sosio kultural dengan lingkungan di mana perusahaan berada serta dapat dimintai pertanggung jawaban layaknya subjek hukum pada umumnya. Sementara itu, menurut Argenty (2010) corporate responsibility disebut juga sebagai corporate social responsibility membentuk kehormatan sebuah organisasi bagi kepentingan masyarakat yang ditunjukkan dengan mengambil rasa memiliki dari efek aktivitas terhadap konstituen kunci termasuk konsumen, karyawan, pemegang saham, komunitas dan lingkungan serta dalam semua bagian dari operasi mereka. Akuntabilitas sering meluas melebihi pelaksanaan dasar dengan peraturan-peraturan yang ada untuk mencakup usaha-usaha sukarela dan proaktif untuk meningkatkan kualitas hidup karyawan dan keluarga mereka begitu pula bagi komunitas lokal dan masyarakat luas.

\section{Teori Stakeholder}

Menurut teori stakeholder perusahaan merupakan entitas yang bukan hanya beroprasi untuk kepentingannya sendiri namum harus memberikan manfaat bagi stakeholdernya (pemegang saham, kreditor, konsumen, suplier, pemerintah, masyarakat, analis dan pihak lain). Dengan demikian, keberadaan suatu perusahaan sangat dipengaruhi oleh dukungan yang diberikan oleh stakeholder kepada perusahaan tersebut (Chariri \& Ghozali, 2007).

Istilah stakeholder memiliki banyak nilai metaforis yang bertujuan untuk mengalihkan perhatian, baik manajerial dan pemegang saham guna untuk memaksimalkan keuntungan (Bampton, 2010). Stakeholder juga dikonseptualisasikan perusahaan sebagai agregasi dari kelompok atau individu yang mempengaruhi atau dipengaruhi oleh aktivitas perusahaan.

\section{Manfaat Corporate Sosial Responsibility}

Menurut Susanto (2009) manfaat yang dapat diperoleh dari aktivitas CSR yaitu: 1) mengurangi resiko dan tuduhan terhadap perlakuan tidak pantas yang diterima perusahaan; 2) CSR dapat berfungsi sebagai pelindung dan membantu perusahaan meminimalkan dampak buruk yang diakibatkan suatu krisis Keterlibatan dan kebanggaan karyawan; 3) CSR yang dilaksanakan secara konsisten akan mampu memperbaiki dan mempererat hubungan antara perusahaan dengan para stakeholder- 
nya; 4) Meningkatkan penjualan.

\section{Prinsip Corporate Social Responsibility}

Ada bebarapa prinsip yang dapat dijalankan dalam melaksanakan program CSR. Menurut Hadi (2011) indikasi kegiatan CSR melalui 3 prinsip utama yakni keberlanjutan (keberlanjutan), akuntabilitas (pertanggungjawaban) dan transparansi (keterbukaan).

\section{Teori Pelaksanaan Corporate Social Responsibility}

Perusahaan harus bertanggung jawab atas semua konsekuensi yang ditimbulkan kepada para stakeholder. Ada 5 dasar teoritis yang kuat bagi perusahaan untuk melaksanakan tanggung jawab sosialnya, yaitu: 1) teori stakeholder; 2) teori legitimasi; 3) teori sustainabilitas korporasi; 4) teori political economy; 5) teori keadilan; 6) evaluasi corporate social responsibility; 7) leadership (kepemimpinan); 8) proporsi bantuan; 9) transparansi dan akuntabilitas; 10) cakupan wilayah (coverage area); 11) perencanaan mekanisme, monitoring dan evaluasi; 11) pelibatan stakeholder (stakeholder engagement); 12) keberlanjutan (sustainability); 13) hasil nyata (outcome).

\section{Dasar Hukum Corporate Social Responsibility}

Dasar hukum CSR meliputi: 1) Undang-Undang Nomor 25 Tahun 2007 tentang Penanaman Modal (UU PM); 2) Undang-Undang Nomor 40 Tahun 2007 tentang Perseroan Terbatas (UU PT); 3) Keputusan Menteri Keuangan Nomor 232/KMK.013/1989 tanggal 11 Nopember 1989 tentang Pedoman Pembinaan Pengusaha konomi Lemah dan Koperasi melalui Badan Usaha Milik Negara (BUMN); 4) Peraturan Pemerintah Nomor 32 Tahun 1998 tentang Pembinaan dan Pengembangan Usaha Kecil; 5) Undang-Undang Nomor 19 Tahun 2003 tentang BUMN; 6) UndangUndang Nomor 20 Tahun 2008 tentang Usaha Mikro, Kecil dan Menengah; 7) UndangUndang Nomor 13 Tahun 2011 tentang Penanganan Fakir Miskin; 8) Peraturan Menteri Sosial RI Nomor 13 Tahun 2012 tentang Forum Tanggung Jawab Dunia Usaha Dalam Penyelenggaraan Kesejahteraan Sosial. 


\section{METODE PENELITIAN}

Penelitian ini merupakan penelitian deskriptif, artinya penelitian akan dibahas dalam bentuk paparan yang diuraikan dengan kata-kata secara cermat dan seteliti mungkin untuk memperoleh informasi tentang status suatu gejala saat penelitian dilakukan. Metode pendekatan yang digunakan dalam penelitian ini adalah pendekatan kualitatif. Hal ini dikarenakan penelitian ini merupakan proses pelaksanaan corporate social responsibility yang dilakukan melalui kajian terhadap perilaku dan pelaku yang terlibat didalamnya dalam mempertahankan citra perusahaan serta bertujuan untuk menggali fakta yang kemudian dideskripsikan dengan pedoman observasi, butir-butir pertanyaan dalam wawancara dan olah dokumentasi di lapangan. Penelitian ini dimaksudkan untuk mengetahui tentang penerapan CSR PT. Industri Gula Glenmore dalam mempertahankan citra perusahaan seperti apa adanya. Data yang dihasilkan dalam penelitian ini adalah data yang berupa kata-kata atau kalimat yang kemudian ditarik kesimpulan. Analisis data yang digunakan dalam penelitian ini bertujuan untuk mengetahui penerapan CSR, evaluasi CSR dan penarikan kesimpulan.

\section{HASIL PENELITIAN}

Hasil penelitian menunjukkan bahwa PT. IGG melaksanakan beberapa hal berikut ini, yaitu: 1) prinsip keberlanjutan, hal ini dibuktikan dengan pelaksanaan program kemitraan yang tiap tahun terus menerus memiliki mitra binaan baik yang sudah mandiri maupun yang masih baru. Dikarenakan dana itu bergulir, jika mitra sudah dapat dikatakan mandiri (meminjam modal ke bank dengan pinjaman yang lebih besar), maka uang tersebut untuk mitra binaan baru. Selanjutnya untuk program bina lingkungan setiap tahunnya ada bantuan sarana prasarana umum untuk desa-desa sekitar PT. IGG, bantuan pendidikan masyarakat setiap 6 bulan sekali. Program yang lain seperti bantuan bencana alam, pelestarian alam dan lainnya tergantung kebutuhan masyarakat; 2) pertanggungjawaban, setiap triwulan melaporkan program-program yang sudah terealisasi berikut dananya kepada direktur; 3) prinsip kedermawanan, memberikan bantuan berupa dana sosial kepada masyarakat yang kurang mampu, membagikan gula kepada setiap masjid pada saat bulan ramadhan.

Selanjutnya yaitu, 4) prinsip transparansi, semua kegiatan langsung dilaporkan karena nanti juga akan di audit oleh auditor KAP (Kantor Akuntan Publik). Dalam melaksanakan program kemitraan dan bina lingkungan tersebut, perusahaan telah 
metetapkan sasaran wilayah oleh PT. IGG dalam proses perencanaannya. Pelaksanaan CSR di PT IGG dilaksanakan melalui 2 (dua) program yaitu program kemitraan,dan program bina lingkungan.

\section{Program Kemitraan}

Program PKBL yang dijalankan oleh PT. IGG dikemas dalam bentuk pinjaman bagi para pengusaha kecil dan menengah. Bentuk pinjaman yang dilakukan oleh PT. IGG meliputi: 1) pinjaman jangka panjang, yaitu pinjaman untuk membiayai modal kerja dan atau pembelian aktiva tetap dalam rangka meningkatkan produksi dan penjualan; 2) pinjaman jangka pendek (khusus), yaitu pinjaman yang digunakan untuk membiayai kebutuhan dana pelaksanaan kegiatan usaha mitra binaan yang bersifat jangka pendek dalam rangka memenuhi pesanan dari rekanan usaha mitra binaan; 3) hibah, digunakan untuk membiayai kegiatan yang terkait dengan manajerial yaitu seperti pelatihan dan yang terkait dengan pemasaran, yaitu seperti pameran dan promosi produk unggulan mitra binaan.

Sementara itu besar kecilnya dana yang dikucurkan dalam program kemitraan ini memang berbeda-beda setiap tahunnya. Hal tersebut karena jumlah laba yang didapatkan perusahaan juga berbeda-beda sebagaimana telah disebutkan di atas. Selain karena besar kecilnya laba yang diperoleh, adanya perbedaan jumlah dana yang digunakan juga disebabkan karena perubahan perundang-undangan itu sendiri. Jika di tahun 2013 pemerintah meminta setiap perusahaan negara (BUMN) untuk mengalokasikan $2 \%$ dari laba yang diperoleh untuk pelaksanaan program ini, maka di tahun 2014 dinaikan menjadi $4 \%$, dan di tahun 2015 ini diturunkan kembali menjadi $3 \%$.

\section{Kondisi Laporan Dana Kemitraan}

Berdasarkan laporan terbaru PT. IGG dalam penyaluran bantuan kerjasama atau kemitraan menunjukkan bahwa tidak semua bantuan berjalan lancar.

Keterangan:

$$
\begin{array}{ll}
\text { 1= Pertanian } & 3=\text { Perikanan } \\
2=\text { Peternakan } & \text { 4= Lainnya }
\end{array}
$$


Tabel 1.

Kondisi Laporan Dana Kemitraan

\begin{tabular}{cccccc}
\hline \multirow{2}{*}{ Tahun } & \multicolumn{5}{c}{ Sektor } \\
\cline { 2 - 6 } & $\mathbf{1}$ & $\mathbf{2}$ & $\mathbf{3}$ & $\mathbf{4}$ & Total \\
\hline Lancar & 10 & 7 & 6 & - & 23 \\
\hline Kurang lancar & - & 1 & 4 & - & 5 \\
\hline Diragukan & 1 & - & - & - & 1 \\
\hline Macet & 1 & 1 & - & - & 2 \\
\hline Jumlah & 12 & 8 & 10 & - & 31 \\
\hline
\end{tabular}

\section{Program Bina Lingkungan}

Program bina lingkungan yang dijalankan oleh PT. IGG merupakan sebuah program yang diwujudkan dalam bentuk bantuan-bantuan sosial kepada masyarakat. Sama dengan program kemitraan, program ini juga merupakan kewajiban bagi perusahaan yang dibebankan oleh pemerintah bagi setiap badan usaha milik negara (BUMN). Program ini dibagi dalam beberapa sendi, seperti: bencana alam, pendidikan, kesehatan, sarana prasarana umum, sarana ibadah, dan pelestarian alam.

\section{PEMBAHASAN}

Berdasarkan hasil penelitian, berikut merupakan penjabaran beberapa program PKBL yang telah dan sedang dilaksanakan oleh PT. IGG:

\section{Bantuan Dana Pendidikan}

PKBL pendidikan berupa pemberian beasiswa kepada siswa berprestasi di tingkat SD dan SMP. Hal ini merupakan program rutin yang dilakukan oleh PT. IGG bekerjasama dengan Dinas Pendidikan Kabupaten Banyuwangi memberikan kepada 32 siswa SD, SMP dan SMA. Dalam memberikan beasiswa ini, PT. IGG hanya sebatas menerima data dari Dinas Pendidikan Banyuwangi. Adapun proses seleksi dan penjaringan siswa- iswa berprestasi tersebut dilakukan oleh Dinas Pendidikan sendiri, sehingga PT. IGG (Unit PKBL) ketika peneliti berikan pertanyaan lebih lanjut, mengenai apa dasar pemberian beasiswa tersebut tidak bisa menyebutkan dengan jelas. Mengingat PT. IGG hanya mendapatkan data dari Dinas Pendidikan kepada siapa-siapa saja beasiswa tersebut layak untuk diberikan. 


\section{Pembangunan Sarana Prasarana Umum}

Membangun sarana-prasana umum adalah salah satu program yang dilalukan PT. IGG dalam melaksanakan program Bina Lingkungan ini. Banyak sarana-prasana yang telah dibangun oleh PT. IGG, seperti misalnya: pengerasan jalan di sekitar lokasi pabrik, pembangunan gapura dukuh dan kampung, pembuatan toilet umum dan lain sebagainya. Pada umumnya, program-program pengadaaan sarana-prasarana ini adalah permintaan dari masyarakat sendiri yang menginginkan adanya perbaikan saranaprasarana di tempat tinggal mereka. Untuk mendapatkan bantuan tersebut, masyarakat mengajukan permohonan dana kepada PT. IGG, kemudian akan dilakukan survei terkait bisa tidaknya permohonan tersebut disetujui. Jika program tersebut disetejui, maka kemudian masyarakat sendirilah yang melakukan pembangunan sarana-prasarana tersebut secara swadaha. PT. IGG hanya sebatas memberikan dana dan monitoring terhadap pelaksanaan kegiatan pembangunan sarana-prasarana. Dengan adanya monitoring yang dilakukan, diharapkan proses pengerjaan sarana-prasana dapat berjalan dengan baik sesuai dengan harapan dari masyarakat. Monitoring ini tidak hanya dilakukan saat sarana-prasana sudah selesai dibangun, namun juga saat proses pengerjaan.

\section{Pelayanan Kesehatan Gratis dan Bantuan untuk Orang Sakit}

Dalam bidang kesehatan, program PKBL ini diwujudkan dalam bentuk pengobatan gratis bekerjasama dengan Puskesmas. Pengobatan Gratis banyak mendapatkan antusiasme dari masyarakat. Terbukti tidak kurang dari 450 masyarakat yang mengikuti pengobatan gratis tersebut. Ada yang memeriksa gula darah, tekanan darah, kolesterol, demam, flu, batuk, gigi, mata dan lain sebagainya.

\section{Pelestarian Lingkungan}

Upaya-upaya terhadap pelestarian lingkungan juga senantiasa dilakukan PT. IGG. Salah satunya adalah dengan memberikan bibit-bibit tanaman ke warga sekitar. Pemberian bibit tanaman tersebut dilakukan untuk menghijaukan daerah sekitar perusahaan. Pemberian bibit tanaman dilakukan sendiri oleh staff di unit PKBL dengan mendatangi rumah-rumah warga di Desa. Masyarakat sendiri menerima baik pemberian bibit tanaman tersebut. Adapun bibit tanaman yang diberikan adalah bibit tanaman 
buah-buahan dan obat- obatan. Selanjutnya pemberian tanaman ini diharapkan dapat ditingkatkan lagi cakupan wilayahnya, tidak hanya di daerah perusahaan ini sendiri. Selain Unit PKBL, pemberian tanaman kepada masyarakat ini juga pernah dilakukan oleh Unit Pengelolahan Tanaman PT. IGG. Tidak hanya sekedar membagikan tanaman kepada masyarakat, tetapi Unit Tanaman juga melakukan upaya edukasi kepada masyarakat terkait dengan pembudidayaan tanaman.

Secara keseluruhan, hasil penelitian menunjukkan bahwa CSR yang dilakukan oleh PT. IGG sudah baik, namun pada kegiatan monitoring yang dilaksanakan masih belum maksimal, dimana terdapat masalah berupa pengembalian pinjaman dari mitra binaan yang terhenti. Menurut Santoso \& Raharjo (2014) permasalahan ini mungkin terjadi karena komitmen masyarakat untuk bermitra dengan perusahaan dalam rangka kegiatan CSR masih belum siap, sehingga banyak program kegiatan CSR yang mengarah untuk pemberdayaan masyarakat terhenti di tengah jalan atau tidak sinambung (sustainability).

Ketidaklancaran pelaksanaan CSR juga ditemukan pada penelitian Harianto (2016), dimana ia menemukan bahwa sebelumnya pelaksanaan CSR tidak pernah mendapatkan keluhan dari masyarakat, tetapi setelah pergantian Kepala Desa muncul hambatan dalam pelaksanaannya. Kepala desa yang baru menjabat belum mendukung penuh atas program ini.

Menurut Frynas (2009) pertimbangan suatu perusahaan untuk melakukan kegiatan CSR antara lain umumnya karena alasan-alasan berikut: 1) untuk memenuhi regulasi, hukum dan aturan; 2) sebagai investasi sosial perusahaan untuk mendapatkan image yang positif; 3) bagian dari strategi bisnis perusahaan; 4) untuk memperoleh licence to operate dari masyarakat setempat; 5) bagian dari risk management perusahaan untuk meredam dan menghindari konflik sosial.

Santoso \& Raharjo (2014) menyatakan bahwa seharusnya pelaksanaan CSR oleh seluruh perusahaan tidak lagi dilakukan semata-mata untuk mendapatkan keuntungan sebesar-besarnya bagi pemilik modal atau pemegang saham, melainkan juga memberikan manfaat pada masyarakat pada umumnya dan pada komunitas sekitar. Berbagai dampak sosial, ekonomi dan lingkungan yang timbul akibat berdirinya suatu kawasan industri mengharuskan perusahaan untuk bertanggung jawab seoptimal mungkin kepada publik melalui aktivitas yang nyata. 


\section{SIMPULAN}

Pimpinan turut andil dalam pelaksanaan CSR di PT. IGG. Transparansi berupa pelaporan kegiatan CSR dilakukan setiap tiga bulan sekali dengan cakupan wilayah yaitu pada masyarakat sekitar PT. IGG. Adapun pada kegiatan monitoring yang dilaksanakan masih belum maksimal, dimana terdapat masalah berupa pengembalian pinjaman dari mitra binaan yang terhenti. Pelibatan stakeholder yaitu pada program kemitraan. Hasil nyata ditunjukkan oleh mitra binaan yang sudah berhasil mandiri. Program Kemitraan dan Bina Lingkungan berlanjut setiap tahun.

\section{DAFTAR PUSTAKA}

Amin, F. (2012). Dampak Limbah Cair Pabrik Gula dan Pabrik Spritus (PGPS) Madukismo terhadap Produktivitas Padi di Desa Tirtonirmolo Kecamatan Kasihan Kabupaten Bantul. S1 Thesis. Universitas Negeri Yogyakarta

Argenti, P. A. (2010). Corporate Communication. Jakarta: Salemba Humanika

Ariana, P. (2018). Pelaksanaan Corporate Social Responsibility (CSR) pada Perusahaan PT. PLN (Persero) Pembangkitan Sumatera Bagian Utara. Skripsi. Universitas Sumatera Utara

Azheri, B. (2012). Corporate Social Responsibility. Jakarta: PT. Raja Grafindo Persada

Chariri, A., \& Ghozali, I. (2007). Teori Akuntansi. Semarang: Badan Penerbit Universitas Diponegoro

Frynas, J. G. (2009). Beyond Corporate Social Responsibility, Oil Multinationals and Social Challenges. Cambridge: Cambridge University Press

Hadi, N. (2011). Corporate Social Responsibility. Yogyakarta: Graha Ilmu

Harianto, R. C. (2016). Evaluasi Program Corporate Social Responsibility "Organic Integrated System" PT. Pembangkitan Jawa-Bali Unit Pembangkitan Paiton. Jurnal E-Komunikasi, 4(1), 1-12

Lako, A. (2011). Dekonstruksi CSR dan Reformasi Paradigma Bisnis dan Akuntansi. Jakarta: Erlangga

Santoso, M. B., \& Raharjo, S. T. (2014). Corporate Social Responsibility (CSR) dari Sudut Pandang Perusahaan. Share Social Work Journal, 4(1), 13-29

Susanto, A. B. (2009). Reputation-Driven Corporate Social Responsibility. Jakarta: Erlangga

Undang-Undang Perseroan Terbatas (UUPT) Nomor 40. (2007). Perseroan Terbatas. https://jabar.bpk.go.id/files/2009/03/UU-40-2007-Perseroan-Terbatas.pdf 